Article

\title{
Feminisms and the Hijāb: Not Mutually Exclusive
}

\author{
April L. Najjaj
}

Department of Humanities and Social Sciences, Texas A\&M University—San Antonio, San Antonio, TX 78251, USA; alnajjaj@gmail.com or anajjaj@tamusa.edu

Received: 19 May 2017; Accepted: 20 July 2017; Published: 25 July 2017

\begin{abstract}
The hijab (veil) is the traditional head covering worn by Muslim women throughout the world. In the West, the hijab has come to symbolize an assumed institutionalized oppression of all women in the Muslim world. Many outside Western observers believe that women who wear a veil are forced to wear it, whether by families, husbands, or governments, and examples of the extremes-Afghanistan, Iran, and Saudi Arabia—are often considered the norm for all Muslim countries. In reality, the situation is more complex. Using a survey done at the Gulf University for Science \& Technology in Kuwait in 2013 (published as "The Veil in Kuwait, Gender, Fashion, Identity"), not only religious concerns but also social and cultural considerations, personal taste and identity, geographic location, socio-economic level, and occasionally conscious rejections of Western influence can all play a part in the decision whether or not to wear a veil. In this preliminary study, I consider this survey as a case study, together with the theory of post-colonial feminism, to find a more nuanced and realistic understanding about the hijab as well as contributing to the development of less Western-oriented definitions of feminism.
\end{abstract}

Keywords: feminism; veil; postcolonialism

In the waning years of the Andalusi Umayyad caliphate of Al-Andalus (750-1031 CE), with its capital in Córdoba (in what is today Spain), the ruler, or khalifat, al-Mustakfi Billah (r. 1023-1025, also known as Muhammad III) had a daughter named Wallada (1001 or 1011-1091). I mention her to you today because in virtually every way, Wallada, as a woman who lived in the 11th Century, defied every stereotype that exists, even in the modern day, in the West regarding Muslim women. She was highly educated, refused to wear a veil, never married or had children, moved freely throughout the city, openly took two long-term lovers, and hosted a literary salon where she invited all the important writers, poets, and political figures of her day. (Farhi 1999; Al Shindagah 2005) Wallada was a poetess in her own right, and although only nine of her poems have survived, these works give us a glimpse into the life of a woman who defied convention, wasn't a victim, and exercised control and agency over her own actions and lived to a ripe old age in a time of great political and social turmoil (Segol 2009).

My first academic training was as a medieval historian studying the Middle East, and the history of Wallada bint al-Mustakfi was one of my first experiences in dealing with historical Muslim women that encouraged me to question the inherent assumptions that exist in the West in the modern day concerning Muslim women, and especially about the veil. Dating from the 11th Century with Wallada (and even earlier if we go back to the time of the Prophet Muhammad and the beginnings of Islam in the 7th Century CE), we can find women who defied the common stereotypes and assumptions that have often existed in the West that paint all Muslim women with the same brush-regardless of geography, ethnicity, religious affiliation, or social class, all are assumed to be passive, submissive, oppressed victims controlled by their fathers or their husbands with no agency over their own lives-and the most obvious physical manifestation of that oppression is the hijāb, the veil.

In a closer examination of not only the veil but of the broader issue of the supposed oppression of Muslim women in general, the origins of these attitudes can be seen in a variety of places. Even 
dating back to the Middle Ages, accusations of promiscuity against the Prophet Muhammad because, for example, he had multiple wives, have been perpetuated in the West and can still be found in criticisms of Islam and Islamic culture down to the modern day. To be more precise, the generally accepted definition of the "West" includes 19th Century European countries (and, by extension, the United States) where colonialism began the modern-day processes of superiority that many in these countries still feel towards developing regions of the world, whether in the Middle East, Africa, Latin America, or parts of Asia, together with the common belief and expectation that these other regions aspire to be like the West. Those attitudes today have evolved somewhat away from the actual physical occupation of colonies, and instead to a post-colonial world of political, economic, and cultural imperialism that perpetuates, in the words of Edward Said, "Europe's historical envy, fear, and hatred of the 'infidel' and supplemented by its sense of superiority over the Islamic world." (Khan 2002, p. 308). Such Orientalist attitudes of Western superiority led to broad paternalistic assumptions of Third World "Other" women, or women from developing countries, as "religious, family-oriented, legal minors, illiterate and domestic" while Western feminists would describe themselves as "sexually liberated, free-minded, [and] in control of their own lives" (Tyagi 2014, p. 49; Mohanty et al. 1991, p. 68). These differences in life experiences and in geography, if nothing else, should not make the "Western" woman and the "non-Western" woman polar opposites, for there are many other issues to be considered in this debate than a traditional, First World Western feminist perspective would suggest (Mishra 2013; McCann and Kim 2010). Issues of capitalism, a sensationalist media, extremist interpretations of Islam, globalization, and what Chandra Talpade Mohanty refers to as 'ethnocentric universalism,' an attempt by many second-wave Western feminist writers to attempt to create a universal sisterhood of sorts, assuming "identical interests and desires, regardless of class, ethnic, or regional location, [that] implies a notion of gender or sexual difference or even patriarchy which can be applied universally and cross-culturally"-basically an assumption of a universality of women's issues-an assumption I believe to be overly simplistic, culturally insensitive, and ignorant of the many shades and nuances of women's experiences throughout the world, whether Western or not (Mohanty 2003, p. 52).

Feminism in any form cannot be studied in a vacuum in any culture. Historical, social, cultural, and religious influences, the legacies of colonialism, expressions of nationalism, levels of education, differences between urban versus rural life, and something as simple as personal preference-all play a part in the place of women in any given society. In considering expressions and definitions of feminism in a non-Western context, I think postcolonial theory is a good place to start; however, traditional postcolonial theory has been male-centered and usually only considers women in the sense of their traditional roles before the arrival of Europeans. What is needed here is a broader approach in postcolonial theory that can incorporate the female perspective and can consider the evolving roles of non-Western women in a postcolonial world. (Gillis et al. 2007) In addition, the term 'postcolonial' can be tricky, as its most common usage suggests that the colonial experience is over-which it's not. The legacies of colonialism are still very much a part of the societies and cultures of any place that experienced colonial rule, whether the Middle East, Africa, Asia, or Latin America, so I think there is still a lot of work to be done in defining postcolonial feminism as a tool for analyzing the feminine experience and its representation (Abu-Odeh 1991; Ashcroft et al. 2006).

An important aspect of postcolonial theory that I think needs to be further elaborated is that not all countries experienced imperialism and colonial rule to the same extent or in the same way. For example, Kuwait's experience with colonial rule was fairly benign compared to many other countries in the Middle East. The British started taking interest in the region that is today Kuwait in the late 19th Century because of its strategic location at the northern entrance to the Persian Gulf. The local ruler of the region, Mubarak al-Sabah (r. 1896-1915), an ancestor of the family that rules Kuwait today, signed a treaty in 1899 that essentially gave Britain control over the country's foreign policy. The relationship was further solidified at the beginning of World War I when the British declared Kuwait a protectorate in order to keep the Ottoman Empire from exerting influence in the region. 
The country was saved from grinding poverty in the 1920s and '30s when oil was discovered, and the British were instrumental in developing the Kuwaiti oil fields. Independence was negotiated without a struggle in 1961, and Kuwait has gone on to become one of the wealthiest countries in the world, depending on oil wealth and a foreign work force to create the welfare state that Kuwaiti citizens enjoy today (Al-Nakib 2014; Cleveland and Bunton 2016). Before the Iraqi invasion in 1990, the country had been more secular and Western-oriented, but many Kuwaitis sought refuge in Saudi Arabia during the Iraqi occupation, and the Saudi help in rebuilding the country once the war was over was contingent upon re-imposing conservative Muslim values, such as gender-segregated schools and classrooms, a prohibition on alcohol, encouraging the wearing of hijäb, etc. The invasions of Afghanistan and Iraq as a response to the 9/11 attacks in the United States also played a part in an increase in anti-Western sentiments emerging in places like Kuwait where it hadn't been such a problem before.

Returning to the specific issue of the hijāb, the practice of veiling is not unique to the Muslim world. Going back to the medieval and even the ancient worlds of what is today the Mediterranean region and the greater Middle East, wearing a veil was not religion-specific but instead was a sign of social status; only slaves and prostitutes did not wear veils (Ahmed 1992). Vestiges of the practice of veiling can still be found in the West with weddings, funerals, and with religious groups, such as Catholic nuns, orthodox Jews, the Amish, and conservative Mormons, so it is not as foreign a practice as many in the West have come to believe. In 7th Century Arabia, during the beginnings of Islam, the wives of the Prophet Muhammad wore veils as a way to mark their status and to cover them from the eyes of the many visitors who came to the Prophet's home in his role as the leader of the new Muslim community. However, in the Qur'an, the only reference to veiling comes in Sura 24, which translates to say,

"Direct the believing women to restrain their looks and to guard their senses and not to disclose any part of their beauty or their adornments, save that which is apparent thereof. They should draw their headcoverings across their bosoms; and should not disclose any part of their beauty or their adornments save to their husbands or to their [families] ..." (Khan 1991, p. 341)

In the Muslim world today, for the most part, wearing hijäb means covering everything but the face and the hands in loose-fitting clothing that encourages modesty. There are some interpretations of covering that are more conservative, where women will wear gloves and a niqā $b$ covering the lower part of the face and revealing only the eyes, but these extremes are more the exception than the rule.

From 2013-2015, I worked as an Assistant Professor of History at the Gulf University of Science \& Technology in Kuwait, and whenever I was back in the U.S. on semester break or for the summer, and I mentioned to someone that I worked in the Middle East, the first question I almost always heard from anyone, whether male or female, academic or layperson, was "Do you have to wear a veil?" or, from the less well-informed, "Do you have to wear that thing on your head?" That was the first thing that any Westerner thought of when confronted with a woman who lives in the Muslim world. They were often surprised to find out that not only did I not wear "that thing on my head", but a good half of my Kuwaiti students didn't, either. In fact, when compared with the many challenges I did face as a Western woman alone working in the Middle East, whether or not to wear a veil was the least of my worries.

Much of the literature regarding feminism and the Muslim world is country-specific, and studies on the Gulf region are sorely lacking in current scholarship. An attempt to fill that void has been done by two of my former colleagues at Gulf University of Science \& Technology in Kuwait in the form of a sociological study concerning the hijāb done in April 2013. Their results were published in a monograph entitled The Veil in Kuwait, Gender, Fashion, Identity (Botz-Bornstein and Abdullah-Khan 2014). In this study, they prepared questionnaires to give to students at the university for female students who veil (which could be wearing the veil with Western clothes, the abaya with a veil, and those who wore the abaya, veil, and niqāb), female students who didn't veil, and male students, with the point being to see the different meanings the students attributed to veiling, whether male or female 
(Botz-Bornstein and Abdullah-Khan 2014, p. 7). Sample questions in the survey were related to why did or why didn't the female student wear hijāb, whether the student gets more or less respect wearing it, if wearing it is related to religious practice or belief, whether their mothers did or did not wear it, and the education levels of their parents. There was also an interesting debate within the responses about whether a woman could wear hijāb and be fashionable at the same time-we'll get to that later.

Before getting into the results of the study, it is important to make note of the group who is being surveyed. Gulf University of Science \& Technology was founded in 2002 and serves a student population primarily from the Gulf region. The vast majority (although not all) of the student population are from Kuwait and are usually citizens who have benefitted in varying degrees from the welfare state that has been created in Kuwait as a result of oil wealth. As a result, the survey represents the opinions of students who are largely on the upper end of the socio-economic scale and whose families have at least somewhat benefitted from the political and social programs of the Kuwaiti government. Also, these students are the generation who were born and matured in the years immediately after the Iraqi invasion and the increase in conservatism encouraged by neighboring Saudi Arabia, so attitudes regarding these issues are influenced by those historical facts.

In carrying out sociological research such as this survey, there are challenges in doing a project like this in a non-Western culture, and the writers of the study were aware of these difficulties. Questioning of society or of religious beliefs and practices is, in and of itself, a Western practice, and not commonly done in non-Western cultures. In fact, in the Comments section provided in the survey, a number of students voiced their opposition to such questions. In their eyes, religious tradition is not to be questioned; the believer does what he or she thinks or has been taught that the religion expects in terms of dress and codes of behavior, and such things should not be open to examination. An additional challenge comes from many students not believing in the confidentiality of such a study, and thus were hesitant to give their real or true opinions for fear of retribution from professors, the college administration, or even their families, so their responses were often just repetitions of the 'party line', so to speak, meaning simply re-stating the religious clichés they thought the sponsors of the study or the college administration would want to hear without any real or critical consideration of their own beliefs. Also, the Kuwaiti education system is one that stresses rote memorization over independent ideas or critical thinking, so many students have never really learned how to examine or express their own opinions and simply rely on what they have been told by those in authority. Also, Kuwaiti students are very familiar with Western media and the biases and assumptions that exist in the West regarding the perceived backwardness or oppression of Islamic belief and culture, so a number of participants in the study doubted the objectivity of the researchers and believed the study would be biased against Islam regardless of what the participants wrote in the survey, despite the fact that one of the two authors of the study is of Pakistani origin and wears hijāb herself. Lastly, even though the authors of the study don't emphasize this, I wondered how much the language barrier played a role in the responses. Instruction at the university is largely in English, but students come to the university from a variety of secondary school settings and with varying levels of skill in English, so I'm sure that how well the students could read and understand what the survey questions were asking for played a part in the results as well.

An important distinction about covered and uncovered girls' perceptions of each other can be seen in that the number one reason for wearing the hijāb given by the covered girls was because of their religion, while the girls who didn't cover believed the others did wear a veil because their families forced them to wear it. Nevertheless, $87 \%$ overall-both covered and uncovered girls as well as the boys-believed that wearing hijāb was obligatory for Muslim women-a high number-and indicates the religious conservatism found throughout Kuwait at this age and level of the society (Botz-Bornstein and Abdullah-Khan 2014, p. 40). We can also see this in the comments of the uncovered girls who didn't wear a veil now but planned to in the future, when they were older or got married (Botz-Bornstein and Abdullah-Khan 2014, p. 13). It was an ideal to aspire to, even if it was postponed to an indefinite future. Such sentiments, I think, can in part be linked to the social and political 
developments in Kuwait in the last twenty-five years resulting from the Iraqi invasion and subsequent Saudi influences in the country. It is interesting to note that very few respondents in the Kuwait survey reported that they wore hijāb to avoid unwanted male attention or to feel more protected while in public. For most Kuwaiti citizens, for example, who are the vast majority of students at Gulf University, public transportation is unnecessary, as most have their own cars or drivers, and so never take a bus and rarely need a taxi. In addition, in traditional Muslim society, individuals are seldom alone; whether male or female, they are usually with friends or family, and thus opportunities for unwanted male attention, although it still happens, are less common in a majority Muslim country like Kuwait, at least among the socio-economic class included in the survey.

Although some writers have contended that Muslim women sometimes wear a veil as a form of protest against Western political and cultural influences, in this study, less than $1 \%$ of the covered girls reported wearing hijāb as a way to reject Western culture (Botz-Bornstein and Abdullah-Khan 2014, p. 24). Kuwait is a wealthy country and has created a very consumer-oriented society that has completely 'bought in' (so to speak) to Western consumer culture, and the large shopping malls, American fast food chains, and veils with designer labels (Gucci, Yves St. Laurent, Louis Vuitton, etc.) can be seen everywhere.

However, the idea of wearing hijäb, yet still being fashionable, produced a contradiction in the study that I found quite interesting. On the one hand, the purpose of wearing a veil is to follow the Islamic religious injunction for women to dress modestly; yet, wearing fashionable clothes would seem to suggest just the opposite, a desire to attract attention rather than to discourage it. In the results, $41 \%$ of female students who covered considered that the hijāb could be a fashion item, but others qualified that by saying that it should still be worn in the traditional way so that it wasn't too fashionable and thus defeated the purpose of wearing the veil in the first place (Botz-Bornstein and Abdullah-Khan 2014, pp. 15,51). I can personally attest that in observing a number of my students at the university, they were following the letter of the law but not the spirit of it, as there were times that I observed students wearing very tight and revealing clothes, but they always had that veil on. In addition, the debate over the veil and its possible expression as fashion is important, as it demonstrates that within the Muslim world itself, there are differences of opinion over interpretations of the faith in the modern day, including the wearing of hijab (Hunter 2009). In my own conversations with female students at the university, several reported that sometimes boys were not interested in a girl who wore hijäb because he didn't want to be perceived as conservative or backward. However, the reverse was true, also-some boys refused to have anything to do with a girl who didn't wear a veil. Whether or not to veil is a debate within and without the Muslim world, not only as a religious expression but also as a cultural one, and Muslim women not only in Kuwait but throughout the world find themselves in the midst of a debate over their choice of dress that, at times, puts them in difficult and even dangerous situations.

The last point I would like to make regarding the survey is the responses given to the question, "Do you believe that men and women are equal?" 70\% of all groups, covered and uncovered girls as well as boys, said yes, men and women are equal (Botz-Bornstein and Abdullah-Khan 2014, p. 13). However, the cultural and religious context should be included here to better understand this response. "Equality" doesn't mean the same thing in Muslim culture as it does in the West; it's more of a 'separate but equal' context, where men have their roles to play in the society, and women have their roles, and these different roles should complement each other, not compete with each other, which is more of a Western perspective on the issue. Islamic society is one that places more emphasis on the family and the community and less on the individual, making questions like equality between men and women less emphasized in the greater context of the well-being of the family and the community as a whole.

With that last question regarding equality is an example of the inherent lack of understanding that often happens between Muslim and Western cultures. As many Third Wave feminists have argued, the different ethnicities, histories, cultures, and societies between the West and the rest of the world should clearly demonstrate that feminism, as a Western construct, is not a one-size-fits-all 
proposition. In recent years, the literature has reflected the emergence of different feminisms (plural), and transnational, postcolonial, and even Islamic feminism are several of those different interpretations. The situation in the Muslim world is yet more complicated when the legacies of colonialism, economic and cultural imperialism, poverty, and political instability are poured into the mix. As Therese Saliba explains it in the Introduction to the book, Gender, Politics, and Islam, "Modernity has brought about an identity crisis among the formerly colonized peoples of the Middle East and South Asia, in particular, and among Muslims, in general, who may seek a form of alternative modernity that is not contingent on embracing westernization." (Saliba et al. 2002, p. 12). Shahnaz Khan refers to this middle ground as a "Third Space" between Islam and Orientalism where Muslim women can navigate their own ways through the expectations and demands placed on them on a daily basis-that's what all women do (Khan 2002, pp. 305-36). We all find our own ways through the social, cultural, and religious values that we have been raised with and pick through it all to live our lives the way we choose, and we use the different tools that have been provided to us to be able to do that. For Muslim women, the veil can be one of those daily tools for moving through the public world. For example, in Rethinking Muslim Women and the Veil, Challenging Historical \& Modern Stereotypes, Katherine Bullock writes about the $h i j \bar{a} b$ as allowing women access to outside employment as well as a way to gain respect and avoid sexual harassment. She specifically mentions the case of an Egyptian woman who negotiated with her future in-laws to allow her to work outside the home by agreeing to wear hijāb, for wearing the veil indicated that "she was a respectable woman who would care for and respect her husband and home ..." (Bullock 2002, p. 101). Agreeing to wear a veil gave her an opportunity that would have been difficult, if not impossible, otherwise.

In addition, Islam is not a monolithic belief system where all Muslims believe the same way-this is a common but erroneous assumption made in the West. In the Christian tradition, for example, there are those who would describe themselves as Christian, but they don't necessarily go to church every Sunday. They are culturally Christian, but it's not a big part of their daily lives. The same is true in the Jewish and Muslim traditions, too. In the case of Islam, there are very devout practitioners who pray every day and carefully live according to the expectations of the religion, and there are others who are only culturally Muslim-meaning they identify as Muslim but may not pray every day, maybe fast during Ramadan, and don't wear hijāb, perhaps because their interpretations of the faith are different, or that religious observance just isn't that important to them. The point here is that every woman, no matter where she is from or where she lives, deserves the right to agency, to find her own place within her own cultural and/or religious context, and just because she chooses differently than what someone else might choose doesn't mean she's oppressed or she doesn't know her rights or her husband or family are forcing her to dress or act in a certain way. A part of the bigger picture of any theory of feminism should be to respect the choices of all women, regardless of their location, ethnicity, religion, or culture.

And that issue of choice is the last one I would like to point out from the survey. In the comments contributed by the male students participating in the survey, a large majority mention that women should not be forced to wear hijäb. They suggest that it is better if they do wear it, but only if it is their choice. In the entire survey, not one respondent, either male or female, believed that women should be forced to wear $h i j \bar{a} b$ - in direct opposition to the often-made Western assumption that all women are forced to wear it (Botz-Bornstein and Abdullah-Khan 2014, p. 36). Of course, it does happen at times that women are pressured to wear it by family or friends, but in theory at least, it is supposed to be her choice.

I consider myself a "practical feminist" or even a "personal feminist", meaning that my interest in feminism is concerned more with the daily interactions of women in moving through their specific worlds and living satisfying and fulfilling lives-in whatever way each woman defines that fulfillment—rather than expounding great, all-encompassing theories that reduce all women's experiences to a continual struggle against oppression. In the Western feminist tradition of the 1960s, for example, not every woman in America was involved with the feminist movement or voted for the 
Equal Rights Amendment. I asked my mother once whether she had been involved with the feminist movement, and she told me that she had been too busy as a single mother working and raising two children to have time for marching in the streets and protesting. Just as in the West, some women in the Muslim world are interested in bringing about change for the status of women, and others, for various reasons specific to their own experience, aren't interested in change. For those who are interested, I would suggest that the hijäb can be an expression of feminism and serve as one of the tools that allows a woman in the Muslim world to better her own life experience, rather than struggle under the blanket assumption that the veil is by default a symbol of women's oppression.

In addition, the assumptions that are often part of the Western feminist tradition, as well as the traditional, largely patriarchal perspective of postcolonial theory, create an intersectionality of discrimination against Muslim women. The Western assumptions of oppression and lack of agency, together with the postcolonial emphasis on returning to original cultural traditions, places the identity politics of women who wear hijāb in doubled or overlapping states of discrimination. As Kimberlé Crenshaw writes, "The problem with identity politics is not that it fails to transcend difference, as some critics charge, but rather the opposite-that it frequently conflates or ignores intragroup differences" and does not consider the intersection of identities (Crenshaw 1993, p. 1242). No one is only a man or a woman, an adult or child, a Muslim or Christian; all people identify with multiple groups at the same time, and that fact is important to being able to recognize the whole person, and not just one aspect of that person. For Muslim women, deciding whether or not to wear a veil is a reflection of the different aspects of her life-as a woman, a mother, a daughter, a Muslim, and within the context of her own life to decide the best ways to be able to function and to live her life within her own cultural context. Life is full of trade-offs, and we all navigate our own cultural contexts to be able to do what we value, whether that's getting an education, getting married, having children, working outside the home, etc.

In closing, let me share with you a little anecdotal evidence for my assertion of the importance of cultural considerations in any study of feminism in the non-Western context. I remember one morning while I was living in Kuwait, I went to the supermarket. I got the things that I needed and headed to wait in line to check out. When I got to the line, I looked at the woman ahead of me: she was wearing a veil and abaya, and her cart was overflowing with bread, milk, eggs, and meat, so it was clear that she was cooking for a large family. As a product of my Western culture, and in standing in line letting my mind wander as we all do at the checkout counter, I started imagining what her life might be like in having to cook and clean and care for a large family, no time to herself, etc. As I looked up at her with pity in my eyes, I saw that same pity reflected in her eyes as she was looking at me-a woman alone with only a few things in her cart and obvious that she was cooking for no one but herself. My point is that cultural values and differences are so important when dealing with women's issues throughout the world, and a "one size fits all" feminism is unacceptable. The world is a beautifully diverse and complex place, and locating women within that place is the goal of feminist studies; however, it's a goal that must be broadly defined and must acknowledge that diversity and complexity in all its many forms.

Acknowledgments: This is a conference paper presented at the 2017 Conference on the Global Status of Women and Girls, Christopher Newport University, Newport News, VA, USA, 24-26 March 2017.

Conflicts of Interest: The author declares no conflicts of interest.

\section{References}

Abu-Odeh, Lama. 1991. Post-Colonial Feminism and the Veil: Considering the Differences. New England Law Review 6: 1527-37. Available online: http://scholarship.law.georgetown.edu/facpub/1401 (accessed on 16 March 2017).

Ahmed, Leila. 1992. Women and Gender in Islam. New Haven: Yale University Press.

Al-Nakib, Farah. 2014. Revisiting Hadar and Badū in Kuwait: Citizenship, Housing, and the Construction of a Dichotomy. International Journal of Middle East Studies 46: 5-30. [CrossRef] 
Ashcroft, Bill, Gareth Griffiths, and Helen Tiffin, eds. 2006. The Post-Colonial Studies Reader, 2nd ed. London and New York: Routledge.

Botz-Bornstein, Thorsten, and Noreen Abdullah-Khan. 2014. The Veil in Kuwait, Gender, Fashion, Identity. New York: Palgrave MacMillan Publishers.

Bullock, Katherine. 2002. Rethinking Muslim Women and the Veil, Challenging Historical and Modern Stereotypes. Herndon: The International Institute of Islamic Thought.

Cleveland, William L., and Martin Bunton. 2016. A History of the Modern Middle East, 6th ed. Boulder: Westview Press.

Crenshaw, Kimberlé. 1993. Mapping the Margins: Intersectionality, Identity Politics, and Violence against Women of Color. Stanford Law Review 41: 1241-99. Available online: socialdifference.columbia.edu/files/socialdiff/ projects / Article_Mapping_the_Margins_by_Kimberle_Crenshaw.pdf (accessed on 14 July 2017). [CrossRef]

Farhi, Moris. 1999. Classical Poems by Arab Women. Translated by Abdullah al-Udhari. London: Saqi Books. Available online: www.poetrymagazines.org.uk (accessed on 18 October 2015).

Gillis, Stacy, Gillian Howie, and Rebecca Munford, eds. 2007. Third Wave Feminism: A Critical Exploration, 2nd ed. New York: Palgrave MacMillan.

Hunter, Shireen T., ed. 2009. Reformist Voices in Islam, Mediating Islam and Modernity. London: M.E. Sharpe.

Khan, Muhammad Zafrulla, trans. 1991. The Quran. New York: Olive Branch Press.

Khan, Shahnaz. 2002. Muslim Women: Negotiations in the Third Space. In Gender, Politics, and Islam. Edited by Therese Saliba, Carolyn Allen and Judith A. Howard. Chicago: University of Chicago Press.

McCann, Carole R., and Seung-kyung Kim, eds. 2010. Feminist Theory Reader, Local and Global Perspectives, 2nd ed. New York: Routledge.

Mishra, Raj Kumar. 2013. Postcolonial feminism: Looking into within-beyond-to difference. International Journal of English and Literature 4: 129-34. Available online: www.academicjournals.org/IJEL (accessed on 16 March 2017).

Mohanty, Chandra Talpade. 2003. Under Western Eyes: Feminist Scholarship and Colonial Discourses. In Feminist Postcolonial Theory: A Reader. Edited by Reina Lewis and Sara Mills. New York: Routledge.

Mohanty, Chandra Talpade, Ann Russo, and Lourdes Torres, eds. 1991. Third World Women and the Politics of Feminism. Bloomington: Indiana University Press.

Saliba, Therese, Carolyn Allen, and Judith A. Howard, eds. 2002. Gender, Politics, and Islam. Chicago: University of Chicago Press.

Segol, Marla. 2009. Representing the Body in Poems by Medieval Muslim Women. Medieval Feminist Forum 45: 147-69. Available online: www.ir.uiowa.edu (accessed on 18 October 2015).

Tyagi, Ritu. 2014. Understanding Postcolonial Feminism in relation with Postcolonial and Feminist Theories. International Journal of Language and Linguistics 1: 45-50.

Al Shindagah. 2005. Wallada bint al-Mustakfi, The Poetess of Andalus. Available online: http:/ / www.alshindagah. com/Novdec2005/woman.html (accessed on 18 October 2015).

(C) 2017 by the author. Licensee MDPI, Basel, Switzerland. This article is an open access article distributed under the terms and conditions of the Creative Commons Attribution (CC BY) license (http://creativecommons.org/licenses/by/4.0/). 